\title{
Design of the railway track infrastructure of the subpolar and northern regions
}

\author{
Gennady Akkerman ${ }^{1,}$, Sergei Akkerman ${ }^{1}$, and Aleksandr Mironov ${ }^{2}$ \\ ${ }^{1}$ Ural State University of Railway Transport, 620034 Yekaterinburg, Russia \\ ${ }^{2}$ Infotex AT LLC, 620049 Yekaterinburg, Russia
}

\begin{abstract}
The interest in the development of the Subpolar and Northern regions of the Eurasian and the American continent has sharply increased recently, which is reflected, among other things, in construction of railways. This construction is associated with large resource costs. The purpose of this work is to study the possibility of using "new" materials ice, sulfur concrete for construction of railway beds. The paper presents results of computer simulation of the "wheel-rail" interaction, which made it possible to investigate the loads onto the ice base, in the "Universal Mechanism" software package. It was determined that the load was less than permissible. The technique of laboratory (with the help of a jack) and field (moving by a steam locomotive) tests of the ice base was described. It was determined that the geometry of the track was not changed under the load. This observation and the computer simulation allows believing that the ice railway beds can be used in the Subpolar and Northern regions.
\end{abstract}

\section{Introduction}

About $70 \%$ of the territory of Russia belongs to the Northern and Arctic zone, which is characterized by permafrost and severe climate. For comparison, in Canada this territory occupies 40\%. The Northern and Arctic territories of Russia are rich in natural resources: oil and gas, coal, non-ferrous and rare metals, diamonds, etc. There are also ports of the Northern Sea Route, which is the shortest sea link from the East to the West. Development of the northern regions of the Eurasian and American continents [1-4] is a special governmental task.

The shape of the railway transport system in this region is formed on the basis of the analysis of design and construction of roads in such conditions: China-Tibet Railway, the Labrador Railway in Canada, northern railway lines of Russia. Computer simulation results, laboratory and full-scale tests performedat the "Tracks and Constructions of Railways” Department of the Ural State University of Railway Transport in Yekaterinburg, Russia, allowed proposing a new track infrastructure design.

Studies have shown that construction and operation of railways in the area considered faces a number of differences as compared to other areas. In particular, this is extremely high cost of infrastructure construction. For example, costs for construction of the Northern Latitudinal Way is $334 \div 404$ million rubles $/ \mathrm{km}$, and the construction cost of the railway to

\footnotetext{
* Corresponding author: GAkkerman@usurt.ru
} 
the Obskaya-Bovynenko-Karskaya railway to the Yamal peninsula is 227 million rubles $/ \mathrm{km}$ $[5,6]$.

The existing approaches to design and construction of railways in these conditions are based on increasing the required resources, which causes an increase in their cost. Therefore, there is a need to create alternative, reliable and economically viable approaches to designing the railway infrastructure for the subpolar and northern regions, which is the purpose of this paper. The results of studies in the design and construction of railways in the Northern regions do not "radically" affect the material of which the railway bed is built, its layout and profile [3-5].

The work is devoted to computer simulation of loads on the ice sheet of the railway with the "wheel-rail" interaction. Confirmation of computer results was obtained by laboratory and field tests, which proved the invariability of the geometry of the ice rail track under real loads from the rolling stock.

In $[3-6,8]$, the emphasis is on preserving the consistency of the permafrost soils in earth railway beds. Nothing is discussed about the "ice beds", "non-melting ice" or sulfur concrete in construction of track infrastructure, about the possibility of changing the track "geometry". This work is performed with the purpose of reducing the resources required for railway communication in the Subpolar and Northern regions.

Various types of transport often operate in the transportation system of northern regions, such as rail, road, river and sea. With small initial cargo flows, in order to reduce the construction cost, road automobile traffic including road trains is arranged along the route of the future railway [7]. With the increase of cargo flow, the upper railway track structure is laid and the road traffic is replaced by railway traffic.

The role of the railway is sharply increased if it is part of the international transportation corridor. For example, it can be part of the South-North international corridor (Azerbaijan, India, Iran, Russian Federation are interested in it) [8]. Belkomur is part of this corridor. Unpredictable weather conditions in the north can often disrupt the operation rate of the multimodal transport chain (for example, sea-railway). It is necessary to create multimodal transportation and logistic centers (MTLCs) to manage the risks of failures. The following are positive features of MTLCs: (1) intermodality (multimodality); (2) synergistic effect, the effect of combining and managing the links of supply chains. Logistical services in northern areas can reach up to $50 \%$ of the value of goods in the cost of production $[9,10]$. It is desirable to use intelligent transport systems (ITS) to reduce the cost of multimodal transportation in the North. Due to high cost of construction and operation, the payback period of certain railways of this area exceeds 20 years. For example, due to the long payback period, the sale of the Obskaya-Bovynenko-Karskaya railway (with the book value of $\sim 130$ billion rubles) to the Yamal peninsula (Russia) from Gazprom to Russian Railways JSC is complicated.

To reduce the railway construction cost, it is possible to use materials that are not quite usual, but are applicable in the conditions of the extreme North. In the absence of local soil to fill the railway bed, it is proposed to use ice instead.

Cryolithozone has been developed for more than 100 years. The Labrador railway (Canada), the Alaska railway (USA), the Norilsk railway (Russia), the Yamal railway (Russia), the Qinghai-Tibet railway (China), the Baikal-Amur Mainline, the AYAM (Amur-Yakut railway, Russia), etc., were partly built on the permafrost. The main disadvantage of ice soils is subsidence during thawing or heaving during freezing $[10,11]$.

Mechanical properties of ice are important [10-14]. Elastic properties of ice are manifested at short-term loads. With constant exposure (even small), plastic strain of ice is observed (for example, the slow "flow" of the glacier in the mountains). The destruction of ice in bending begins at pressure $P_{\mathrm{LL}}=1.5 \mathrm{MPa}$, and with compression $P_{\mathrm{LL}} \approx 3 \mathrm{MPa}$ (30 $\mathrm{kg} / \mathrm{cm}^{2}$ ) [12-14]. 
It should be noted that the average pressure along the axis of the railway bed from the upper railway track structure $P_{\mathrm{URTS}}=0.016 \mathrm{MPa}$ and from the rolling stock $P_{\mathrm{RS}}=0.84$ $\mathrm{MPa}$, i.e., total

$$
\begin{gathered}
P=P_{\mathrm{URTS}}+P_{\mathrm{RS}}=0.86 \mathrm{MPa}, \\
\text { i.e., } P_{\mathrm{LL}}>P .
\end{gathered}
$$

Significant strength of ice was assumed when building the following ice crossings: across LakeBaikal (with the "initial" operation of the Trans-Siberian Railway), across the Volga near Saratov in 1928, across the Northern Dvina in Arkhangelsk (1943 to 1944), across Lake Ladoga (the "Road of Life", etc.) .

The strength of ice can be increased technologically, using the "thin films" principle and by changing its composition. Thin films of crystallized water are stronger than "ordinary" ice: they do not have heat shrinkable shells and cracks. The thin films principle is reduced to rapid freezing of granular ice layer by layer.

Thus, in mid-November 1981, ice was frozen on a ferry across the Lena at the air temperature of -32 to $-34^{\circ} \mathrm{C}$ near Yakutsk, Russia. Mobile pumping stations (with the head of $100 \mathrm{~m}$ ) with sprinkler nozzles created a drip cone. The droplets were partially frozen (ice in the cone, approximately 40 to $67 \%$ ) in ice balls on the surface and formed granulated ice, more uniform than natural ice, with water.

The thin films principle is used in Yakutia when building structures: ice is quickly frozen on an inflatable formwork in the form of an arch, layer by layer. The strength of the construction obtained is not less strong than concrete.

Ice concrete, which is ice consisting of pebbles (gravel), sand and water [15], is often used for construction in polar regions. Its strength is equal to "ordinary" concrete, and its bending strength is 2 to 4 times higher than that of concrete or bricks. Ice with inclusion of sawdust, various fibers is 2 to 3 times stronger than "pure" ice $[16,17]$. It withstands the pressure of up to $5 \mathrm{MPa}$. Ice reinforcement with fiberglass increases its strength by almost 8 times.

Non-melting (a chemically inert substance, sulfur concrete) can melt and freeze repeatedly. The melting point is about $150^{\circ} \mathrm{C}$, it retains strength and hardness up to $70^{\circ} \mathrm{C}$ and conducts heat poorly. It is not hazardous to humans. Laboratory and full-scale tests of ice-frozen rails were performed at the static load of 10 tons at our department.

\section{Research method}

The test bench was a frame welded of steel channels with the following dimensions: height - $160 \mathrm{~mm}$, width - $64 \mathrm{~mm}$, thickness - $5 \mathrm{~mm}$. The frame corners were reinforced with gussets. The frame was buried vertically into the ground to the depth of $50 \mathrm{~cm}$. In winter, at the air temperature of minus $20^{\circ} \mathrm{C}$, an ice prism (instead of a ballast prism) was built (on layers of $4-5 \mathrm{~cm}$ ) on frozen soil, $30 \mathrm{~cm}$ high and $122 \mathrm{~cm}$ wide on both sides of its axis. A rail with the length of $12.5 \mathrm{~m}$ of mark P-50 (height of $150 \mathrm{~mm}$, sole width of $132 \mathrm{~mm}$, head height of $33 \mathrm{~mm}$ ) was laid on the prism by dragging through the frame. The rail was frozen into the ice by layers on one side to the level of the rolling track and on the other side on the rail head. The width of the ice prism along the top of the rail axis was $76 \mathrm{~cm}$ on one side (half of the track width) and $50 \mathrm{~cm}$ on the other side.

The load on the rail, measured with a manometer, was created by a hydraulic jack with the maximum force of 10 tons, which corresponds to the pressure on the crew axis of 20 tons. Rail deformations were determined: vertical ones by an optical level; horizontal ones by a metal ruler from the basis set earlier. The experiment was performed 5 times at negative air temperature: $8^{\circ} \mathrm{C}, 11^{\circ} \mathrm{C}, 14^{\circ} \mathrm{C}, 21^{\circ} \mathrm{C}, 16^{\circ} \mathrm{C}$. 


\section{Results}

The rail geometry remained unchanged for all tests. The same result was obtained for the load from the locomotive (at speeds of $5,10,15 \mathrm{~km} / \mathrm{h}$, the load of 16 tons per axis). The steam locomotive ran three times on ice-frozen rails $12.5 \mathrm{~m}$ long without sleepers. If it is assumed that only one running meter of the rail works under one axis, then the pressure on the ice is less than $0.4 \mathrm{MPa}$.

Tram tracks that consisted of rails without sleepers, filled with plastic (polypropylene) were tested in Strasbourg (France) with positive results. The filling thickness was about 40 $\mathrm{cm}$.

In construction of railway beds not of earth but of ice in the Subpolar regions, the "thin films" technology must be applied. It is desirable to reinforce ice with geogrids, better (but not necessarily) with the ones manufactured by German company "HUESKER". For example, it can be rigid FOZTZAC geogrid with the strength of up to $3,000 \mathrm{kN} / \mathrm{m}$. To the south, the width of the main site must be increased for thermal insulation at least $0.5 \mathrm{~m}$. It is possible to use the "non-melting ice" (sulfur concrete). The basis of sulfur concrete is "sulfur polymer cement" or elemental sulfur with a large proportion of its polymeric allotropes and a small percentage of additives (stabilizers) [18].

See the comparison of sulfur concrete and cement concrete in Table 1.

Table 1. Comparison of sulfur concrete and cement concrete.

\begin{tabular}{|c|c|c|c|}
\hline Indicators & $\begin{array}{c}\text { Units of } \\
\text { measurement }\end{array}$ & Sulfur concrete & Cement concrete \\
\hline Frost resistance & $\%$ & 200 & 100 \\
\hline $\begin{array}{c}\text { Thermal } \\
\text { conductivity }\end{array}$ & $\%$ & 66 & 100 \\
\hline $\begin{array}{c}\text { Strength: } \\
\text { compression }\end{array}$ & $\mathrm{MPa}$ & $55-65$ & $10-60$ (up to 100) \\
\hline bending & $\mathrm{MPa}$ & $10-15$ & $5-8$ \\
\hline elongation & $\mathrm{MPa}$ & $5-7$ & $0.5-4$ \\
\hline $\begin{array}{c}\text { Time required to } \\
\text { reach } 50 \% \text { strength }\end{array}$ & hours & 0.3 & 100 \\
\hline Cost of $1 \mathrm{~m}^{3}$ & $\%$ & 50 & \\
\hline
\end{tabular}

Portland cement concrete is based on irreversible chemical reaction of hydration, and sulfur concrete is based on a reversible process of cooling the liquid melt (the melting temperature is 120 to $150^{\circ} \mathrm{C}$ ).

Embankment construction: ice is built up to the required mark using thin film technology in accordance with the previously installed back slopers, the ice layers are reinforced with a geogrid at a given location. "Non-melting ice" is applied onto back slopers by layers. Since this melt is applied in thin layers from the top downwards, the ice of the railway bed does not have time to melt (the thickness of the "shell" made of sulfur concrete is $15-20 \mathrm{~cm})$.

Variants of construction of the "ice bed" can be different: first the it is framed with "non-melting ice", and then its core is filled with ice. The embankment can be made of previously harvested ice cubes "frozen" with each other.

Artificial structures are corrugated metal pipes, or arched pipes made of sulfur concrete, built on inflatable formwork. Film formwork, for example, made of polyvinyl chloride, withstands the temperature of +120 to $+150^{\circ} \mathrm{C}$. The first layers of the melt is poured with cold water, which is evaporated almost immediately. Pipe openings are determined by the 
estimated water flow with the probability of exceeding of $1 / 300$. Such flow rate is adopted to avoid accumulation of water near the artificial structure.

The ballast prism is also made of reinforced ice or "non-melted" ice under the rail 20 to $25 \mathrm{~cm}$ thick. The rails are frozen into ice without sleepers. As reinforced ice holds a "vertical wall" well, the slopes of the bed are made 1:1, i.e., steeper than for existing railways. Excavation is not desirable.

The rails are frozen from the inside of the track to the head, and from the outside - along the walkway (similar to how the city tram ways are "drowned" in the asphalt). The ice-free head of the rail, except for the rolling track, is covered with white paint. Our research has shown that this coating is a good heat insulator.

All surfaces except for the northern exposure to reflect the sun rays are covered with the $0.5 \mathrm{~cm}$ layer of "white" ice, i.e., water plus chalk powder. Construction of the ice sheet of the railway must be performed in winter. For example, summer on the Taimyr Peninsula lasts for only 6 weeks with the maximum air temperature of $+10^{\circ} \mathrm{C}$. Therefore, it is desirable to protect the slopes of embankments and excavations of the southern exposure from the sun by canopies, just in case.

Sun canopies were used on the Qinghai-Tibet railway in China, in some sections of the Baikal-Amur Railway, the Amur-Yakutsk Railway of Russia [5, 9, 19]. It is supposed to make canopies of sandwich panels over the snow-free surface. By protecting the latter from sunlight, the canopy reduces the temperature of the surface underneath it by 3 to $5^{\circ} \mathrm{C}$ and protects it from summer precipitation [20]. Naturally, a system of engineering and climatological monitoring [6] must be created behind ice structures, similar to monitoring the stressed state of a seamless railway track using balises [21]. Implementation of the proposed designs must be preceded by a program of experimental works.

1. As already noted, the subpolar regions are a severe region for human habitation and, therefore, with low population density. Therefore, railways in these areas must be equipped with low amount of personnel, taking into consideration the arrangement of works in shifts both during construction and particularly during operation. That is why it must have a stable layout and profile that do not change its design outline (or low-changeable) under the influence of passing trains (resources will not be required for their straightening). The efficiency of the biclotoidal design of the railway layout and profile was proved by simulation in the "Universal Mechanism" software package (UM) created at the Bryansk State Technical University. UM is an effective tool for simulation of the dynamics of machine behavior. This requirement is met by the biclotoidal design of the curvilinear sections of the layout and profile (the transverse forces are reduced by two times, on average) [22]. There is no need to comply with the existing requirements for the mismatch of the vertical curve in the profile with the transition curves in the layout [23, 24]. Based on the reducing dynamics of the wheel-rail interaction, the track geometry must meet the design requirements, and it is desirable to keep train speeds under $60 \mathrm{~km} / \mathrm{h}(16.7 \mathrm{~m} / \mathrm{s})$, and then the the radius of the vertical curve at the clotoids conjugation point will be as follows with the minimum vertical acceleration of $a_{\mathrm{v}}=0.1 \mathrm{~m} / \mathrm{s}^{2}$ :

$$
R_{\mathrm{B}}=\frac{V^{2}}{a_{\mathrm{B}}} ; R_{\mathrm{B}}=2800 \mathrm{M}
$$

or, after rounding, $R_{\mathrm{v}}=3,000 \mathrm{~m}$.

The value of the limiting (leading) slope must not exceed 25\%. Weight of train $Q$ with locomotive traction $2 \mathrm{TE}-10 Q=1,630 \mathrm{n}, Q_{\mathrm{n}}=1,150 \mathrm{t}$.

In other words, 24 trains/day will be required for every 10 million tons of cargo per year. Then, it is necessary to arrange passing loops every $35 \mathrm{~km}$ with the average speed of $40 \mathrm{~km} / \mathrm{h}$. 


\section{Conclusion}

Thus, under appropriate conditions, the railway transportation system of the Subpolar regions is single-track railways. The layout and the profile are with the minimum number of curves designed by biclotoids. The minimum radius of the vertical curve $R_{\mathrm{v}}=3,000 \mathrm{~m}$ at the clotoid conjugation point in the vertical plane, $i_{\mathrm{p}}=25 \%$, the profile breaks are unlimited and may coincide with the transition curves in the layout. Excavations are not desirable. The lower structure of the path is made of ice, the upper structure is without sleepers, the rails are "drowned" in the ice. With a freight turnover of 10 million tons per $\mathrm{km}$ per year, diesel locomotion and the average speed of trains of $40 \mathrm{~km} / \mathrm{h}$, passing loops must be made each $35 \mathrm{~km}$. Culvert are metal corrugated pipes or pipes made of non-melting ice. Automatic blocking is provided on the basis of the "axis counter".

The nature of the railway transportation system is significantly changing in subpolar and northern regions. Technologies that require low number of personnel are used in the design, construction and operation of railways, therefore:

- design of the layout and the profile of the curvilinear sections reduces the wheel-rail interaction forces by 2 times on average, the track stability is increased;

- it is different from the usual track structure: the lower railway track structure is built of ice in a "shell" of sulfur concrete, the upper railway track structure is without sleepers, the rails are "drowned" in ice;

- maximum automation of transport process control and monitoring. The latter requires GIS (geoinformation systems) and radio tags (balises) installed along the railway at certain distances between them. As a pilot project, traffic of trains without a locomotive crew must be performed in Subpolar regions.

\section{References}

1. The State Program of the Yamalo-Nenets Autonomous District "Development of International Foreign Economic and Interregional Activities for 2014-2020" of 25.12.13 No. 1133-П (2013). (in Russian)

2. Northern strategy of Canada: Our North, Our Heritage, Our Future. Document of Government of Canada (2009). (in Russian)

3. G.A Gross, Yron ore deposits of Canada and the West Yudies (Survey of World iron ore resources, New York, 1970).

4. V.M. Nazarenko, K.S Nazarenko, Transportnoe obespechenie vneshnejekonomicheskoj dejatel'nosti [Transport support of foreign economic activity] (UNITI, Moscow, 2005).

5. V.G. Kondratyev, Collection of reports of the $1^{\text {st }}$ Congress of Russian geocryologists (MSU, Moscow, 1996). (in Russian)

6. V.G. Kondratyev, V.A. Pozin, Koncepcija sistemy inzhenerno-geokriologicheskogo monitoringa strojashhegosja zheleznodorozhnogo puti Barkakit - Tommot - Jakutsk [The concept of the system of engineering-geocryological monitoring of the railway Barkakit-Tommot-Yakutsk] (Zabtrans, Chita, 2000). (in Russian)

7. G.L. Akkerman, S.G. Akkerman, Transport of the Urals, 3, 27 - 32 (2016). (in Russian)

8. W.J. Fend, W. Ma, Z.Z. Sun, G.Y. Li, W.B. Yu., I.E. Zheny. Conf. Proc. IX International Symposium on Perm a frod Engineering, 1 (Mirny, Russia. 2011). (in Russian)

9. N.A. Valiev, V.E. Kondratyev, Inzhenernaja geologija [Engineering geology], 4, 5663 (2015). (in Russian) 
10. SNiP 2.05.07-85. Building regulations. Manual for the design of railways and highways of industrial enterprises in permafrost regions (Gosstroy SSSR, 1990). (in Russian)

11. SP-25-13330. Set of rules. Foundations and foundations on permafrost soils. Updated version of SNiP 2.02.04-88 (Rosstandart, 2012). (in Russian)

12. I.S. Peschanskiy, Inzhenernaja gljaciologija [Engineering Glaciology] (Moscow, 1976). (in Russian)

13. K.F. Voytkovskiy, Mehanicheskie svojstva l'da [Mechanical properties of ice] (Moscow, 1960). (in Russian)

14. I.S. Peschanskiy, Ledovedenie i ledotehnika [Ice science and ice engineering] (Leningrad, 1963). (in Russian)

15. Stroitel'nyj jekspert [Construction expert]. Ice - building material of the past, present and future. Available at: https://ardexpert.ru/article/8185 (December 12, 2016). (in Russian)

16. A.M. Chekotilo, Primenenie snega, l'da i merzlogo grunta $v$ fortifikacii [The use of snow, ice and frozen ground in fortification] (Moscow, 1943). (in Russian)

17. Yu. Semenov, S. Silin, Innovacionnye tehnologii ispol'zovanija l'do-kompozitnyh materialov $v$ stroitel'stve $i$ jekspluatacii plavuchih objektov [Innovative technologies for the use of ice-composite materials in the construction and operation of floating facilities] (Moscow, 2011). (in Russian)

18. PNST 105-2016. Technical conditions. Preliminary national standard. Sulphur concrete mixes and sulphur concrete (Stroitel'stvo, 2016). (in Russian)

19. V. Kondratyev, Inzhenernaja zashhita [Engineering protection] (Moscow, 2015). (in Russian)

20. N. Enjin, Sh. Yongping, Cuide of Field Excursion after Asian Conference on Permafros (Lanshon, China, 2006).

21. G.L. Akkerman, M.A. Skutina, Herald of the Ural State University of Railway Transport, 1, 28-35 (2017). (in Russian)

22. G.L. Akkerman, S.G. Akkerman, O.A. Kravchenko, Zheleznodorozhnyj transport [Railway transport], 5, $41-42$ (2011). (in Russian)

23. G.L. Akkerman, S.G. Akkerman, V.A. Kopylenko, A.V. Zamuhovskiy, Transport Rossijskoj Federacii [Transport of Russian Federation], 1, 22 - 25 (2018). (in Russian)

24. SP 119.13330.2012. Set of rules. Railways with gauge $1520 \mathrm{~mm}$. Updated version of SNiP 32-01-95. (Stroitel'stvo, 2012) (in Russian) 